\title{
Socio-Economic Impact of Desertification on Rural Livelihood in Ganye Southeastern Adamawa State, Nigeria
}

\author{
Jamala, G. Y*, Mada, D. A., Abraham, P and Joel, L \\ College of Agriculture, Ganye, Adamawa State, Nigeria
}

\begin{abstract}
The study was conducted to evaluate the socio-economic impact of desertification on rural livelihood in Toungo, Southeastern fringe of Adamawa State, Nigeria, situated in the Southern Guinea Savanna zone. A total of three hundred (300) respondents (farmers) interviewed were selected using purposive and random sampling techniques. The results of socio-economic characteristics of the respondents (farmers) are presented in Table 1. On the causes of desertification, the respondents (56.7\%) indicated that the main causes of desertification were human activities, $30 \%$ were of the opinion that this was cause by changes in the climate, while $13.3 \%$ of the respondents are ignorant of what causes desertification. When asked about the effect of desertification on their livelihoods, $43.3 \%$ of the respondents indicated that there was reductions in the amount of rainfall receive each year, $40 \%$ pointed out that there was increased in temperature, and $16.7 \%$ maintained that they noticed drying of water bodies. There was a diverse response concerning the impact of desertification on farmer's agricultural activities. $43.3 \%$ of the respondents pointed out that they recorded poor harvest as the result of desertification in the previous years, $36.7 \%$ maintained that they notice an increase in wind erosion, $13.3 \%$ shows that the situation was tending towards a decrease in the availability of pasture for livestock, while $6.7 \%$ revealed that there was a drastic reduction in soil fertility as observed on their farmlands. The results of this study shows that majority of the farmers in the study area are aware about the causes, effects and impact of desertification as it's seriously affects their agricultural productions in diverse ways. At the same time, $56.7 \%$ of the respondents indicated that Aforestation is one of the best strategies for combating desertification, $43.3 \%$ believe that the practice of proper irrigation will be a good strategy, while 10\% maintained that establishment and maintenance of shelter belts will reduce the impact of desertification in the study area. An important issue is how to support the rural poor to use the soils, the biota and other natural resources without destroying those resources, and without affecting the climate adversely.
\end{abstract}

Keywords: Livelihood, Desertification, Impact, Farmers, Forest, Socio-Economics

\section{Introduction}

Desertification is "the intensification or extension of desert conditions leading to reduced biological productivity, with consequent reduction in plant biomass, in the lands carrying capacity for livestock, crop yields and human wellbeing (World Map of Desertification, UNCOD 1977). According to UNCED (1992) desertification is "land degradation in arid, and semi-arid and dry sub humid areas resulting from various factors including climate variation and human activities". Even though, desertification is an age old phenomenon, Thomas and Middleton (1994) pointed out that, it affects countries and people the world over either directly or indirectly.

In the aftermath of the drought of the late 1960's and early 1970's desertification received reviewed interest, and human action such as deforestation, over cultivation, over grazing and irrigation more than climate factors, were now perceived to be chief drivers of desertification and land degradation (Mortimore, 1987, William and Balling, 1996).

According to Kawu (1987:1993), desertification is a process of severe environmental degradation that occurs when the water balance of nature in an ecosystem is disturbed. This could result in the disappearance or permanent degradation of the vegetation. Some factors identified to be associated with desertification include temperature, evaporation and wind, as well as changes of ecosystem equilibrium due to human misuse of resources such as water, land and vegetation.

Other factors causing desertification include wood extraction for fuel and construction, bush burning which emits carbon dioxide, over cultivation of marginal land. One of the impacts of climate change is the increasing incident of drought and desertification.

The demand for fuel wood in the Sahel Zone is high because of the increasing population and rapid urbanization. Wood collection for domestic use is the main cause of deforestation, and this leads to desertification (Thomas and Middleton 1994, NAP, 2000).

The human factor causing desertification is often contributed to inappropriate methods of land use and over population. For example, after the 1960 and 1974 drought it was posited that the production practices of the 
Sahara dwellers might have cause irreversible damage to the environment, which would require a long term recovery process.

The rapid population increase in the dry zone applies human pressure on the land by increasing demands for food, water, fuel, raw materials, and other natural resources beyond the carrying capacity of the land in many situations.

The traditional patterns of land use in the dry land by herders, more especially by nomadic herders, have in many instances been thought of as a poor use of the environment that results in land and soil degradation. It is argued that this occurs when the herd sizes "are allowed to increase in an almost uncontrollable and seemingly irresponsible manner" (Thomas and Middleton, 1994). Over stocking the dry land has been regarded as the major cause of desertification. Overgrazing result when the potential carrying capacity (PCC) of a piece of land has been exceeded or an expression of the way in which herders misuse the environment.

Over cultivation has also been blamed for causing desertification and land degradation. Over cultivation results when the length of fallow period is reduced which leads to nutrient depletion, thus impacting on the potential for production and on the yields of crops. Also, the increasing use of mechanized agriculture in the dry lands also contributes to land degradation and desertification. Since mechanized agriculture utilizes large fields, and has the ability to plough very deep, it damages soil structure. Hence, soil erosion from wind and water "may result from the weaker soil structure" (Thomas and Middleton, 1994).

According to official sources NAP (2000), bush burning is almost likely result in the Sahel due to peasants clearing for agriculture during dry lands; hunters in search of game, set fire on the vegetation, and cattle herdsmen setting fire to dry up grass to stimulate growth of dormant grass buds. The human factors that cause desertification are complicated. Sahelian peasants are forced by hopeless circumstances to deplete the few trees in the Sahel as fuel wood so as to make a living.

\section{Socio-Economic impact of Desertification}

According to Mortimore (1989) desertification and drought were responsible for the rapid increase in prices indices of food stuff and other non oil export, for instance Guinea corn (Sorghum) was affected worse than millet, but some farmers harvested little or neither from less than half drum to little as 10 percent of the expected yields. As for livestock, it was estimated that there had been losses, the death of 4,400 cattle 6,400 sheep, 5,000 goats, and most of the fowls. Mortality in some herds was reported to be 30-50 percent and herds hardly any young had been breed during these years. Almost everywhere, ground water levels had fallen, leaving dry wells, prices of foodstuffs had risen by 400 percent and smaller markets were some times without gain.

The impact of desertification on the socio-economic life of rural households leads to reduction in crop and animal production, as well as causing, livestock deaths and rise in the prices of foodstuffs. People migrate as a consequence of drought and desertification to urban areas or to other rural areas, in order to engage in economic activities such as farming, grazing and fishing (Oladipo, 1993). Migration impacts on family life leads to separation of families-wives and children and ultimately the destruction of family patterns (NAP, 2000; Oladipo, 1993) as women, children and the elderly ones are often left with the burden of agricultural activities.

\section{Rural Livelihood Sustainability}

A livelihood comprises the capabilities assets (stores resource, claims and access) and activities required for a means of living. A livelihood is sustainable when it can cope with and recover from stress and shocks maintain or enhances its capabilities and assets, and provide sustainable livelihood opportunities for the next generation, and which contribute net benefit to other livelihood at the local or global levels and in the short and long term (Chambas and Conway, 1992. Scoones, 1998; Solesbury, 2003; Ashley and Carney 1999)

Rainfall remains a constraint outside the influence of households, and its affects the productive practices. The importance of rainfall for agriculture, especially small holder agriculture, cannot be over emphasized as its variability and scarcity affects sharply the yields and livelihood of farmers.

Bio-productivity is the state of the soil and plant bio- productivity. It is factor within the control of small holders, and depends on the use of sustainable management practice. Rain fed agriculture and animal husbandry are the principal economic activities in the study area. These factors lead to soil and land degradation, which reduces the bio- productivity of the soil and land.

Desertification mostly affects rural households who are forced to depend on natural resources for their livelihoods. More so, drought and desertification lead to the migration of people to urban or other areas to engage in economic activities such as farming, grazing and fishing. Other impacts of desertification are that it could lead to economic and social strife.

Food security remains a top priority for most rural people, including the urban poor that constitute the majority of farmers in the Southern Guinea Savannah of Adamawa State. Contending with low rainfall, depleting soil fertility, and high temperature, farmers adopt various methods to ensure adequate harvests. These 
methods are not infallible and often fall short of providing enough food for these rural poor. To augment their diet, local dwellers must constantly rely on the forest to support their livelihood.

Desertification can lead to widespread poverty, and mostly affects rural households for their livelihoods. Therefore, the study is relevant in seeking to understand how rural households cope with the impact of desertification and land degradation. It also seeks to understand whether there are enabling policies to enhance the livelihood of peasants in marginal environment. The important of forestry in sustainable agriculture through eradication of desertification in the study area cannot be over emphasized.

\section{The study area}

\section{Materials And Methods}

The study was carried out in Ganye Local Government area, located in the Southeastern part of Adamawa State (Longitude $12^{\circ} \mathrm{N}$, Latitude $09^{\circ} \mathrm{E}$ ). It is bounded by Jada to the North, Mayo-Belwa and Taraba State to the West, Toungo to the South and to the East Cameroon Republic (Adebayo, 1999). It has a land mass of about $2291.42 \mathrm{~km}^{2}$ and a population of 164,087 (NPC, 2007). The mean annual temperature of the study area is $26.7^{\circ} \mathrm{C}$ and the mean annual rainfall ranges between $1000 \mathrm{~mm}$ and $1600 \mathrm{~mm}$ with a distinct dry season which begins in November, and ends in April and the wet season begins in April and ends in October or sometimes in November. The area is located within the Guinea Savannah zone of the Nigeria's vegetation Zones (Adebayo 1999). The major economic activity in the area is agriculture, food crops grown in the area includes Maize, sorghum, cowpea, Cassava and Potatoes. While Cash crops such as Ground nuts, Rice, Yam and Sugarcane are produced in large quantities. The famers are also engaged in collection and processing of non-timber forest such as Shea nuts. Major livestock reared in the zones are Cattle, Sheep, Pigs and Goats (Ad seeds, 2004).

\section{Methods of data collection and analysis}

Data were collected from all the communities involved in agricultural activities. A total of three hundred (300) respondents (farmers) interviewed were selected using purposive and random sampling techniques. Information gathered includes: age, gender, marital status, educational level and years of farming experience, major occupation and farm size of the respondents. Others include causes of desertification, impact, government policies and programs in combating the impact of desertification on rural livelihoods. The completed questionnaires were retrieved, coded and subjected to descriptive statistical analysis such as Tables, Frequencies distributions and percentages.

\section{Socio-economic Characteristics of the respondents}

\section{Results And Discussion}

$40 \%$ of the respondents are within the age range of 41-50 years, representing the active part of the population engaged in agricultural activities while, $25 \%$ are within the age range of 30-40 and 51-60 years and $10 \%$ between $61-70$ years respectively (Table 1 ). A good number of the respondents $(73.3 \%)$ are married and $23.3 \%$ are still single (Table 1). This suggest that agricultural practices in the study area is mostly associated with the married individuals and it is also likely that they engaged their family members in farming activities and hence making farm work relatively simple in operation. In the aspect of education, $53 \%$ of the respondents had tertiary education, while $16.8 \%$ had secondary education, $13.3 \%$ non formal education, $3.3 \%$ of the respondents had primary and $13 \%$ neither attended formal no non formal education respectively. This indicates that agricultural activities in this area are mostly dominated by the respondents who had formal education.

Steian (2003) pointed out that education is one of the important human capitals which play important roles in determining status in society. Education is expected not only to contribute to people's ability to read and understand instructions but also help them to adopt new techniques. According (Chigbu et al, 2012), this could lead to more direct employment generation, better economic empowerment and well being of the rural populace. According to Amaza and Tashikalma (2003), the literacy level of farmers is important as it determines the rate of adoption of improved technology for increased productivity. Also, Adekunle (2009) pointed out that the level of education of farmers will directly affects their ability to adapt to change and to accept new ideas.

The result in Table 1 shows that $56.6 \%$ has 16 to 20 years of farming experience and $26.7 \%$ had 11 to 15 years. This shows that with more years of farming experience, farmers tend to be more efficient in production through learning and practicing, therefore, they can also perceive any changes in their production over the years. From Table 1 it can be seen that the di-occupational respondents constitute about $50 \%$. While 50 
percent are full time farmers, which mean that apart from farming activities they do not have other sources of incomes. The diversification serves as a security to the di-occupational farmers should one of the ventures fail.

The farm size varied from 1 to $>10$ ha with the majority (56.7\%) having a farm size of between 1 and 2 hectares. This implies that the respondent's are a typical characteristic of small scale farmer possession a relatively small landholdings use to produce what they need for their own family with little extra being offered for sale. $26.7 \%$ of respondents have a farm size of between 3 and 5 hectares (Table 1). Based on sources of farmland, Table 1 shows that $66.7 \%$ of farmers inherited the farmland, while $20 \%$ acquired the farmland, $10 \%$ lease the farmland, and $3.3 \%$ are those who make use of government land.

\section{Causes, Effects and Impact of Desertification}

In Table 2 the respondents $(56.7 \%)$ indicated that the main causes of desertification were human activities, $30 \%$ were of the opinion that this was cause by changes in the climate, while $13.3 \%$ of the respondents are ignorant of what causes desertification. When asked about the effect of desertification on their livelihoods, $43.3 \%$ of the respondents indicated that there was reductions in the amount of rainfall receive each year, $40 \%$ pointed out that there was increased in temperature, and $16.7 \%$ maintained that they noticed drying of water bodies. There was a diverse response concerning the impact of desertification on farmer's agricultural activities. $43.3 \%$ of the respondents pointed out that they recorded poor harvest as the result of desertification in the previous years, $36.7 \%$ maintained that they notice an increase in wind erosion, $13.3 \%$ shows that the situation was tending towards a decrease in the availability of pasture for livestock, while $6.7 \%$ revealed that there was a drastic reduction in soil fertility as observed on their farmlands. The results of this study shows that majority of the farmers in the study area are aware about the causes, effects and impact of desertification as it's seriously affects their agricultural productions in diverse ways.

\section{Strategies for Combating Desertification}

Table 3 reveals that $56.7 \%$ of the respondents indicated that Aforestation is one of the best strategies for combating desertification, $43.3 \%$ believe that the practice of proper irrigation will be a good strategy, while $10 \%$ maintained that establishment and maintenance of shelter belts will reduce the impact of desertification in the study area.

\section{Conclusion}

Desertification is a well known problem that affects human beings and animals. The integrity of the environment is related to the efficient use and management of available land. The results of this study revealed that farmers and other land users are aware of trends of drought and desertification and the status of land as a result of human activities, and that their understanding of climate variations, desertification and qualitative changes in land are similar to those of scientific findings. On the whole, they perceive that the climate is getting drier due to reduction in rainfall, increase in temperature and land degradation through soil erosion. The need for efficient management of land is the more urgent in the face of an ever-increasing population and the growing demands in all the various activities based on land. Land resources and the processes of their development and use, however, have varying consequences on the environment and specifically land becomes more vulnerable as the result of misuse, which subsequently affects productivity of the land. An important issue is how to support the rural poor to use the soils, the biota and other natural resources without destroying those resources, and without affecting the climate adversely.

\section{Recommendations}

Based on the findings, the following recommendations were made.

i Government should re-introduce tree planting programs annually.

ii Each Local Government in the State should establish a plantation and maintain shelter belts to combat desertification, this could be down by incorporating the rural farmers in the establishment and management aspects.

iii Extension Workers should be motivated by the government to educate rural farmers of some important strategies on how to reduce the menace of desertification in their localities.

iv Forest nurseries should be established in each Local Government Area to enable them raise enough seedlings for planting in the area.

$\mathrm{V}$ Laws against deforestation and bush burning should be strictly enforced.

Vii Funds allocated for the implementation of policies and programs in relation to combating of desertification and its associated impact should not be diverted, but judiciously utilized. 
Table 1: Age Distribution of Respondent

\begin{tabular}{|c|c|c|}
\hline Age & Frequency $\quad \mathrm{N}=\mathbf{3 0 0}$ & Percentage (\%) \\
\hline $30-40$ & 80 & 27 \\
\hline $41-50$ & 120 & 40 \\
\hline $51-60$ & 80 & 27 \\
\hline $61-70$ & 20 & 6 \\
\hline Total & 300 & 100 \\
\hline \multicolumn{3}{|c|}{ Educational Qualification } \\
\hline No formal Education & 40 & 13.3 \\
\hline Adult Education & 40 & 13.3 \\
\hline Primary Certificate & 10 & 3.3 \\
\hline Secondary Certificate & 50 & 16.8 \\
\hline Tertiary Certificate & 160 & 53.3 \\
\hline Total & 300 & 100 \\
\hline \multicolumn{3}{|l|}{ Occupation } \\
\hline Farming & 150 & 50 \\
\hline Trading & 20 & 6.7 \\
\hline Civil servant & 130 & 43.3 \\
\hline Total & 300 & 100 \\
\hline \multicolumn{3}{|l|}{ Farm Size (ha) } \\
\hline $1-2$ & 170 & 56.7 \\
\hline $3-5$ & 80 & 26.7 \\
\hline $6-10$ & 40 & 13.3 \\
\hline 11 and above & 10 & 3.3 \\
\hline Total & 300 & 100 \\
\hline \multicolumn{3}{|l|}{ Source of farmland } \\
\hline Lease & 30 & 10 \\
\hline Inheritance & 200 & 66.7 \\
\hline Purchase & 60 & 20 \\
\hline Government land & 10 & 3.3 \\
\hline Total & 300 & 100 \\
\hline \multicolumn{3}{|c|}{ Farming Experience (Years) } \\
\hline $1-4$ & 10 & 3.3 \\
\hline $5-10$ & 40 & 13.3 \\
\hline $11-15$ & 80 & 26.7 \\
\hline $16-20$ & 170 & 56.7 \\
\hline Total & 300 & 100 \\
\hline
\end{tabular}

(Source: Field Survey, 2012)

Table 2: Causes, Effects and Impact of Desertification

\begin{tabular}{lll}
\hline Causes & Frequency & Percentage \\
\hline Human activities & 170 & 56.7 \\
Change in Climate & 90 & 30 \\
I don't know & 40 & 13.3 \\
Total & 300 & 100 \\
Effects of Desertification & & 40 \\
High temperature & 120 & 43.3 \\
Low rainfall & 130 & 16.7 \\
Drying of water bodies & 50 & 100 \\
Total & 300 & 43.3 \\
Impact of Desertification on Rural Livelihood & & 13.3 \\
Poor harvest & 130 & 36.7 \\
Lack of pasture for L/Stock & 40 & 6.7 \\
Increase in wind erosion & 110 & $\mathbf{1 0 0}$ \\
Reduction of soil fertility & 20 & $\mathbf{3 0 0}$ \\
Total & & \\
\hline
\end{tabular}

(Source: Field Survey, 2012)

Table 3: Strategies for Combating Desertification

\begin{tabular}{lll}
\hline Strategies & No. of Respondents & Percentage \\
\hline Aforestation & 140 & 46.7 \\
Practice of irrigation & 130 & 43.3 \\
Establishment of shelter & 30 & 10 \\
Total & $\mathbf{3 0 0}$ & $\mathbf{1 0 0}$ \\
\hline
\end{tabular}

(Source: Field Survey, 2012) 


\section{References}

[1]. Adams, M.W and Mortimore, M. (1997). Agricultural Intensification and Flixibility in the Sahel. The Geographical Journal. Vol. 163, No. 2 pp. 150-160

[2]. Adekunle, V. A. (2009). Contributions of agroforestry practice in Ondo State, Nigeria, to environmental sustainability and sustainable agricultural production. Afrika Focus -Volume 22, Nr. 2, 2009 -pp. 27-40

[3]. Ashley, c. and Carney, D. (1999). Sustainable Livelihoods: Lessons from early Experience London; Department for International Development.

[4]. Bosorrup, E. (1965). The conditions of Agricultural Growth; The Economics of Agrarian Change under population pressure. London; George Allen and Unwan Ltd. Pergamon Press

[5]. Carney, D. (Ed) (1998). Sustainable Rural Livelihoods: What contribution we make? London: Department for International Development.

[6]. Chambers, R. and Conway, G.R (1992). Sustainable Rural Livelihood for the $21^{\text {st }}$ Century, Discussion paper 296.Brighton, UK: Institute of Development.

[7]. DFID (1999). Sustainable Livelihoods and Poverty Elimination: Background Briefing Available of www ids. Ac. Uk/Livelihoods. Htmlretrieved on $31^{\text {st }}$ March, 2009.

[8]. Ellis, F. (1998). Household Strategies and Rural Livelihood Desertification. Journal of Development Studies 351 Pp 1-38.

[9]. Hermann, S.M. and Hutchinson, C.F (2005). The Changing Contexts of the Desertification Debate. Journal of Arid Environments. 63. $P$ p $538-555$.

[10]. Kawu, U. (1987). "Drought and Desertification in the Sahel and Sudan- Sahel" in Sagua, V. O et al (Edited) Ecological Disasters in Nigeria: Drought and Desertification. Lagos: Federal ministry of Science and Technology pp. $105-113$.

[11]. Kio, P.R.O (2000). "Forestry and Sustainable Agricultural Development" invited paper: National Workshop Enhancing Research and Development in Agriculture and Forestry towards Poverty Alleviation and Rural Development in Nigeria. FRIN. Ibadan 14 to 18 Febuary, 2000.

[12]. Mortimore, M. (1989). Adapting to Drought: Farmers, farming and Desertification in west Africa. New York, Cambridge University press

[13]. Mortimore, M. and Adams, M. (2001). Farmers Adaptation, change and crises in the Sahel. Environmental change II (2001) $49-57$.

[14]. NAP (2000). The National Action Program to combat Desertification and mitigate the effects of drought. Federal Ministry of Abuja, Nigeria.

[15]. Oladipo, E. O, (1993). A Comprehensive Approach to Drought and Desertification in Northern Nigeria. Natural Hazards. 8. 99-261.

[16]. Scoones, I. (1998). Sustainable Rural Livelihood; A Framework for Analysis" Working paper 72,Brighton, UK: Institute for development Studies

[17]. Solesbury, W. (2003). Sustainable Livelihoods: A case study of the Evolution of DFID policy. Working paper 217. London: Overseas Development Institute.

[18]. Thomas, D.and Middleton, N. (1994). Desertification Exploding the Myth. New York. John Wileyand Sons

[19]. Tiffen, M. (1996). Land capital: Blind Spots in the study of the "Resource Poor" farmer".

[20]. UNCED (1992). Earth Summit 92. London the Regency press.

[21]. Williams M.A.J and Balling, R.C (1996). Interactions of Desertification and Climate. London: Arnold.

[22]. WCED (1987). Our common future: Report of the World Commission on Environment and Development. Oxford: University Press.

\section{Acknowledgements}

The authors would like to thank all the respondents who availed us their time during field data collection for this study. 